\title{
Coronary Heart Disease and Return to Work
}

Citation for published version (APA):

de Rijk, A. (2020). Coronary Heart Disease and Return to Work. In U. Bultmann, \& J. Siegrist (Eds.), Handbook of Disability, Work and Health (Vol. 1, pp. 431-450). Springer, Cham. Handbook Series in Occupational Health Sciences Vol. 1 https://doi.org/10.1007/978-3-030-24334-0_24

Document status and date:

Published: 01/01/2020

DOI:

10.1007/978-3-030-24334-0_24

Document Version:

Publisher's PDF, also known as Version of record

Document license:

Taverne

Please check the document version of this publication:

- A submitted manuscript is the version of the article upon submission and before peer-review. There can be important differences between the submitted version and the official published version of record.

People interested in the research are advised to contact the author for the final version of the publication, or visit the DOI to the publisher's website.

- The final author version and the galley proof are versions of the publication after peer review.

- The final published version features the final layout of the paper including the volume, issue and page numbers.

Link to publication

\footnotetext{
General rights rights.

- You may freely distribute the URL identifying the publication in the public portal. please follow below link for the End User Agreement:

www.umlib.nl/taverne-license

Take down policy

If you believe that this document breaches copyright please contact us at:

repository@maastrichtuniversity.nl

providing details and we will investigate your claim.
}

Copyright and moral rights for the publications made accessible in the public portal are retained by the authors and/or other copyright owners and it is a condition of accessing publications that users recognise and abide by the legal requirements associated with these

- Users may download and print one copy of any publication from the public portal for the purpose of private study or research.

- You may not further distribute the material or use it for any profit-making activity or commercial gain

If the publication is distributed under the terms of Article $25 \mathrm{fa}$ of the Dutch Copyright Act, indicated by the "Taverne" license above, 


\title{
Coronary Heart Disease and Return to Work
}

\author{
Angelique de Rijk
}

\section{Contents}

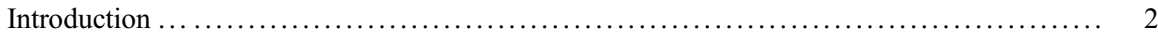

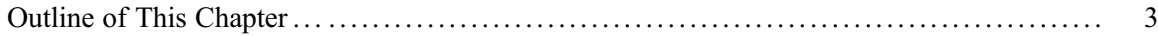

Risk Factors for Recurrence of a Cardiac Event and Barriers for RTW in Employees with

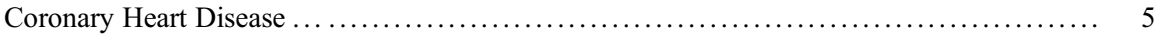

Cardiac Risk Factors ................................................... 5

Work-Related Risk Factors: Psychosocial Risk Factors ......................... 7

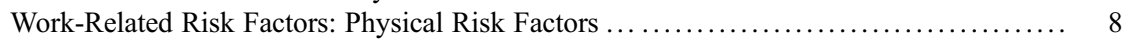

Barriers to a Successful RTW ............................................ 9

RTW Interventions for Employees with Coronary Heart Disease ..................... 11

Recommendations by Experts for the Support of RTW in CR ...................... 11

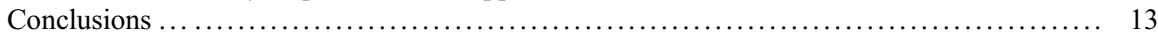

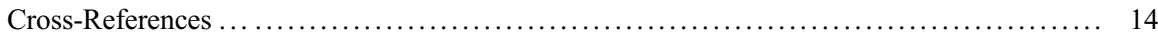

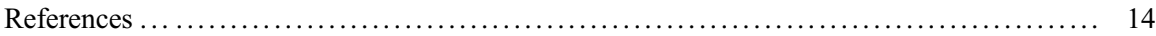

\begin{abstract}
After a cardiac event, up to $80 \%$ of the employees return to work within one year. Cardiac rehabilitation (CR), which focuses on the physical, psychological, and social functioning, contributes to faster return to work (RTW). Specific attention for work-related issues might improve the RTW rate. Three systematic reviews were done on: (1) risk factors in the workplace for cardiac patients; (2) factors that prolonged sickness absence in cardiac patients; and (3) the effectiveness of RTW interventions for cardiac patients. Existing guidelines, expert knowledge of representatives of 11 different health professions, and a working group of psychologists were additionally used to select risk factors and management to
\end{abstract}

\footnotetext{
A. de Rijk $(\bowtie)$

Department of Social Medicine, Care and Public Health Research Institute (CAPHRI), Faculty of Health, Medicine and Life Sciences, Maastricht University, Maastricht, The Netherlands

e-mail: Angelique.derijk@maastrichtuniversity.nl
} 
promote RTW in cardiac patients as part of CR. The reviews, guidelines, and expert knowledge identified four groups of risk factors for RTW: eight cardiac risk factors; four psychosocial job-related risk factors; six physical risk factors; and 17 psychosocial risk factors (barriers to a successful RTW). Positive effects of interventions were found for the more comprehensive interventions. Key recommendations based on scientific evidence and expert advice are targeting via a short intake that eliminates those patients that do not need RTW support; early start of (part-time) RTW during CR; tailor-made RTW support based on individual risk assessment and interventions within and outside $\mathrm{CR}$ that address the individual risks; and frequent communication between the CR team and the workplace (occupational physician), upon patient agreement.

\section{Keywords}

Cardiovascular disease $\cdot$ Coronary heart disease $\cdot$ Return to work $\cdot$ Cardiac rehabilitation $\cdot$ Risk factors $\cdot$ Assessment $\cdot$ Intervention $\cdot$ Tailoring

\section{Introduction}

Generally, $80 \%$ of employees who have been admitted at a hospital for myocardial infarction (MI), coronary artery bypass graft surgery (CABG) ("bypass"), or percutaneous coronary intervention (PCI, an intervention to treat the stenotic coronary arteries) have returned to work after one year (Perk and Alexanderson 2004; Worcester et al. 2014). This rate seems rather stable over the years and populations, but there is room for improvement. Return to work (RTW) can take place faster and become more effective when the RTW support is given earlier (Jelinek 2014) and when the RTW support takes into account patient-specific risk factors (Smedegaard et al. 2017; Reibis et al. 2019).

RTW support can be offered as part of cardiac rehabilitation (CR). CR is delivered in hospitals, in rehabilitation centers, or at local physiotherapists combined with telemonitoring at home (Kraal et al. 2017). It is offered to patients after their stay in the hospital for an acute cardiac condition such as MI, CABG, and PCI. In recent years, it is also offered to patients with more chronic conditions such as heart failure (reduced pumping function of the heart). CR has four goals: (1) physical recovery, (2) psychological recovery, (3) social recovery, and (4) lifestyle improvement. CR improves functional capacity, recovery, and psychological well-being and is cost-effective (Piepoli et al. 2010). Effectiveness lies in CR improving the physical condition, lifestyle (e.g., smoking cessation), medication adherence, and psychological well-being (Piepoli et al. 2010). The latter is of utmost importance since $75 \%$ of cardiac patients have elevated levels of depressive symptoms and/or symptoms of anxiety. About one fifth of cardiac patients suffer from depressive disorder (De Jong et al. 2004; Thombs et al. 2006). These conditions reduce the patient's health status in itself but are also risk factors for recurrent cardiovascular morbidity (disease) and mortality, and, finally, they reduce compliance with medical and lifestyle 
interventions. CR will thus indirectly contribute to RTW by improving physical condition, lifestyle, and psychological well-being.

CR that focuses on physical recovery has been offered to patients since the 1960s. This exercise-based $\mathrm{CR}$ is proven effective in reducing total and cardiovascular mortality and hospital admissions (Jolliffe et al. 2001; Piepoli et al. 2010; Heran et al. 2011). Next, CR has been extended with lifestyle interventions: quitting smoking, active lifestyle, no or moderate alcohol consumption, weight reduction, and healthy diet (reduction in saturated and trans fat, improve the consumption of n-3 fatty acids, improve consumption of fruit and vegetables, and reduce salt consumption). Often, psychological approaches are used to change unhealthy behavior into healthy behavior (Piepoli et al. 2010). CR is well implemented in the Western world although intensity varies (Piepoli et al. 2010).

However, specific attention to work-related issues or RTW is often lacking within CR (Reibis et al. 2019). In some countries, specialized occupational physicians or insurance physicians are available to support patients during their sickness absence and RTW. Only in recent years, specific interventions have been developed, but initially with little success. In their review of studies between 1982 and 2000, Perk and Alexanderson (2004) found no effects of specific RTW interventions for patients after MI, PCI, and CABG. An important aspect that was lacking in these interventions is tailoring to the specific needs of the employee with coronary heart disease, for example, reducing work demands (O'Hagan et al. 2012; Reibis et al. 2019). (Occupational) health professionals need to be aware of the possible patient-specific risk factors for delayed RTW and be able to decide on the individual patient's risk factors and on interventions to decrease or eliminate the patient's risk factors.

\section{Outline of This Chapter}

This chapter aims to familiarize the reader with the specific risk factors for RTW and possible interventions to improve the RTW of employees with coronary heart disease. This knowledge is not only important for research but also for (medical) practice, as most guidelines and directions for cardiac patients do not yet address the work situation or RTW support (cf Piepoli et al. 2016) or only offer broad directions (Reibis et al. 2019). This chapter will therefore address three topics:

1. Factors that impede RTW in employees with coronary heart disease (cardiac risk factors, psychosocial and physical work-related risk factors, and barriers to a successful RTW)

2. Interventions for employees with coronary heart disease that improve their RTW

3. Recommendations by experts for the organization of support of RTW of employees with coronary heart disease including tools (within CR)

Topics 1 and 2 are addressed via systematic reviews of the literature, except for cardiac risk factors and physical work-related risk factors, for which several guidelines already exist (see below). The searches were conducted in the context 
Table 1 Search strategies and quality assessment of reviews

\begin{tabular}{|c|c|c|c|}
\hline \multirow[b]{2}{*}{ Stage } & \multicolumn{3}{|l|}{ Review topic } \\
\hline & $\begin{array}{l}\text { 1. Psychosocial } \\
\text { work-related } \\
\text { risk factors }\end{array}$ & $\begin{array}{l}\text { 2. Barriers } \\
\text { to a } \\
\text { successful } \\
\text { RTW }\end{array}$ & $\begin{array}{l}\text { 3. Interventions for employees } \\
\text { with coronary heart disease that } \\
\text { improve RTW }\end{array}$ \\
\hline \# hits review 2010 & 1220 & 130 & 664 \\
\hline $\begin{array}{l}\text { \# relevant on the basis of } \\
\text { the title } 2010\end{array}$ & 419 & 86 & 300 \\
\hline $\begin{array}{l}\text { \# relevant on the basis of } \\
\text { the abstract } 2010\end{array}$ & 380 & 67 & 216 \\
\hline $\begin{array}{l}\text { \# full articles available } \\
2010\end{array}$ & 291 & 63 & 180 \\
\hline $\begin{array}{l}\text { (\# added on basis of } \\
\text { references 2010) }\end{array}$ & 39 & 14 & 4 \\
\hline $\begin{array}{l}\text { \# met inclusion criteria on } \\
\text { basis of full article } 2010\end{array}$ & 32 & 21 & 14 \\
\hline \# hits review 2018 & \multicolumn{3}{|l|}{152} \\
\hline $\begin{array}{l}\text { \# added on basis of } \\
\text { relevance of title, abstract } \\
\text { and full article } 2018\end{array}$ & 3 & 14 & 3 \\
\hline Total number of articles & 35 & 35 & 17 \\
\hline Quality of studies & $N=35:$ fair & $N=35:$ fair & $N=13:$ fair \\
\hline
\end{tabular}

of developing a multidisciplinary guideline for CR in the Netherlands during 20082011 (van Stipdonk et al. 2011) and done during autumn 2010 for publications in the previous 10 years (and thus not overlapping those in Perk and Alexanderson 2004) in the following databases: PsycINFO, CINAHL, and PubMed. The findings of these searches for the guideline were supplemented by a recent search of literature on RTW in patients with cardiovascular disease (2010-September 2018). The quality of individual studies was assessed (high quality, randomized controlled trial; fair quality, non-randomized trial, cohort study, and patient-control study; low quality, study with major flaws). The search strategy and quality assessment are presented in Table 1.

The conclusions of the reviews will be supplemented by three very recent reviews and recommendations on aspects of RTW of cardiac patients (Gragnano et al. 2018; O'Brien et al. 2018; Reibis et al. 2019). Moreover, the reviews will be supplemented by expert knowledge generated in the context of the guideline development described above. Experts were representatives of 12 scientific societies of professions involved in CR in the Netherlands (cardiologists, psychiatrists, psychologists, rehabilitation physicians, cardiac nurses, occupational therapists, physiotherapists, social workers, occupational physicians, occupational experts, social insurance physicians, and general practitioners). Also, representatives of the cardiac patient's association were involved. The discussions with experts covered 11 meetings over a period of 18 months and resulted in recommendations. In addition to these experts, a temporary working group of nine psychologists advised on psychological 
screening instruments and cutoff points to be used within CR. Thus, first risk factors for the recurrence of a cardiac event and barriers to RTW in employees with coronary heart disease will be addressed, and next evidence for RTW interventions for patients with coronary heart disease and, finally, a RTW support procedure within CR including practical tools will be presented. This chapter will be finished with conclusions for research and practice.

\section{Risk Factors for Recurrence of a Cardiac Event and Barriers for RTW in Employees with Coronary Heart Disease}

When addressing RTW in employees with coronary heart disease, it is important to distinguish between preventing a recurrent cardiac event (through managing cardiac, psychosocial, and physical work-related risk factors) and removing barriers for RTW (by managing risk factors for impaired RTW).

\section{Cardiac Risk Factors}

International and national guidelines (Bjarnason-Wehrens et al. 2004; van Dijk et al. 2006; Piepoli et al. 2010; Reibis et al. 2019) and the experts referred to above agree on eight cardiac factors that might affect work ability and/or increase the chance for recurrence of the cardiac event, possibly in interaction with certain working conditions (see Table 2). Table 2 also presents norms for when a factor is assumed to be a risk factor. First, (1) residual ischemia and (2) reduced heart function (left ventricular ejection factor $<40 \%$ ) are indications that working under heavy circumstances is dangerous. Next, (3) medication for the patient with coronary heart disease might have side effects that interfere with functioning at work. For example, $\beta$-blockers reduce physical endurance and hamper performing heavy physical jobs. Stress at work can provoke (4) arrhythmia (irregular heart rate) and (5) tachycardia (too rapid heart rate), which the treating cardiologist might judge as being harmful, depending on the specific medical condition and level of stress at work. When untreated or resistant to treatment, (6) hypertension is regarded harmful above 160/100 $\mathrm{mmHg}$ and an extra risk for the respective patient for recurrence of a cardiac event. When the work situation demands (7) higher physical endurance than the patients has, this is again a risk for recurrence. Low physical endurance is also a risk for delayed RTW, as two recent studies showed (Salzwedel et al. 2016; Boschetto et al. 2016).

Existence of these cardiac risk factors does not imply that RTW will not be possible. However, they need to be interpreted in relation to the type of work. In practice, occupational health expertise is needed to weigh up the cardiac risk factors in relation to the exposure at work and to formulate recommendations for work adaptations or alternative work (van Dijk et al. 2006) as there is still no agreement on norms (Reibis et al. 2019). 
Table 2 Cardiac risk factors that might interfere with performing work

\begin{tabular}{|c|c|c|}
\hline Cardiac risk factors & Explanation including norms & References \\
\hline 1. Residual ischemia & $\begin{array}{l}\text { Four classes of severity are } \\
\text { distinguished by the New York } \\
\text { Heart Association (NYHA } \\
\text { classes) related to chest pain } \\
\text { when climbing stairs (no } \\
\text { pain = class I; pain after } 3 \text { stairs } \\
\text { of } 15 \text { steps = class II; pain after } 1 \\
\text { stair of } 15 \text { steps = class III) or } \\
\text { even in rest (class IV) } \\
\text { Precise exercise capacity and } \\
\text { ischemic threshold can be } \\
\text { established by bicycle ergometry } \\
\text { or treadmill maximal stress test } \\
\rightarrow \text { Working conditions might } \\
\text { provoke ischemia }\end{array}$ & \multirow[t]{8}{*}{$\begin{array}{l}\text { Bjarnason-Wehrens et al. 2004; } \\
\text { van Dijk et al. 2006; Piepoli } \\
\text { et al. 2010; Boschetto et al. } \\
\text { 2016; Salzwedel et al. 2016; } \\
\text { Reibis et al. } 2019\end{array}$} \\
\hline $\begin{array}{l}\text { 2. Reduced heart } \\
\text { function (left ventricular } \\
\text { ejection factor }<40 \% \text { ). }\end{array}$ & $\begin{array}{l}\rightarrow \text { If reduced, the patient cannot } \\
\text { perform physically heavy work }\end{array}$ & \\
\hline $\begin{array}{l}\text { 3. Medication } \\
\text { (particularly B-blockers) }\end{array}$ & $\begin{array}{l}\rightarrow \text { Side effects might interfere } \\
\text { with working conditions (e.g., } \beta \text { - } \\
\text { blockers reduce physical } \\
\text { endurance) }\end{array}$ & \\
\hline $\begin{array}{l}\text { 4. Arrhythmias (atrial or } \\
\text { ventricular) }\end{array}$ & $\begin{array}{l}\rightarrow \text { Stress or physical work } \\
\text { demands might provoke } \\
\text { arrhythmias }\end{array}$ & \\
\hline $\begin{array}{l}\text { 5. Ventricular } \\
\text { tachycardia (with strain } \\
\text { and stress) }\end{array}$ & $\begin{array}{l}\rightarrow \text { Stress might provoke } \\
\text { ventricular tachycardia }\end{array}$ & \\
\hline $\begin{array}{l}\text { 6. Untreated/therapy- } \\
\text { resistant hypertension } \\
(\geq 160 / 100 \mathrm{mmHg})\end{array}$ & $\begin{array}{l}\text { Treatment is recommended for } \\
\text { hypertension } \geq 140 / 90 \mathrm{mmHg} \text {, } \\
\text { but some patients have low } \\
\text { treatment adherence or their } \\
\text { hypertension is resistant to } \\
\text { therapy } \\
\rightarrow \text { Employees need to have a } \\
\text { blood pressure }<140 / 90 \mathrm{mmHg} \\
\text { during rest }\end{array}$ & \\
\hline $\begin{array}{l}\text { 7. Low physical } \\
\text { endurance tolerance } \\
\text { (determined by an } \\
\text { endurance test) }\end{array}$ & $\begin{array}{l}\text { Precise exercise capacity and } \\
\text { ischemic threshold can be } \\
\text { established by bicycle ergometry } \\
\text { or treadmill maximal stress test } \\
\rightarrow \text { Working conditions should be } \\
\text { below the patient's physical } \\
\text { endurance }\end{array}$ & \\
\hline 8. ICD/PM implant & $\begin{array}{l}\rightarrow \mathrm{ICD} / \mathrm{PM} \text { implant might } \\
\text { interfere with electromagnetic } \\
\text { exposure in the workplace }\end{array}$ & \\
\hline
\end{tabular}




\section{Work-Related Risk Factors: Psychosocial Risk Factors}

There is firm scientific evidence for the relationship between psychosocial work characteristics and coronary heart disease. Primarily, research regarding recurrence of coronary heart disease is relevant for defining risk factors for lack of RTW, but as there is little research on work-related risk factors for impeded RTW - also research regarding the work-related etiology of coronary heart diseases is regarded informative (see Table 3).

Stressors at work are risk factors for RTW in persons with coronary heart disease, as they may increase the chance for recurrent cardiac events. There is moderate evidence regarding job demands and job strain (combination of high demands and low autonomy) in relation to recurrent cardiac incidence. Only for men there is enough evidence that high work demands are a strong prognostic risk factor for a recurrent cardiac event, particularly when combined with low autonomy at work. Recent research of Biering et al. (2015) demonstrated more sickness absence after PCI (percutaneous coronary intervention; see above) when having high demands and low autonomy, however, not an increased risk for cardiac events after RTW - which might be explained by changes in perceived or actual working conditions. Söderberg et al. (2015) showed that acute coronary syndrome (e.g., MI) survivors, who worked under adverse psychosocial work conditions, had lower return-to-work expectations compared to those working under better psychosocial work conditions. Salzwedel et al. (2016), however, found a higher psychosocial workload to increase the probability of RTW. Again, the results were primarily found among men, which could result from few female study participants or gender differences in RTW mechanisms. Gragnano et al. (2018), who reviewed work-related predictors for

Table 3 Psychosocial risk factors for (recurrent) cardiac event

\begin{tabular}{l|l}
\hline Psychosocial risk factors for... & References \\
\hline $\begin{array}{l}\text { 1. High work demands (in combination with } \\
\text { low autonomy) for recurrent cardiac event }\end{array}$ & $\begin{array}{l}\text { Belkic et al. 2004; Eaker et al. 2004; } \\
\text { Malinauskiene et al. 2004; Riese et al. 2004; De } \\
\text { Bacquer et al. 2005; Kivimäki et al. 2006; } \\
\text { Kornitzer et al. 2006; Peter et al. 2006; } \\
\text { Lallukka et al. 2006; Nomura et al. 2007; Wang } \\
\text { et al. 2007; Eller et al. 2009; Bonde et al. 2009 }\end{array}$ \\
\hline $\begin{array}{l}\text { 2. High effort-reward imbalance for first } \\
\text { cardiac event }\end{array}$ & $\begin{array}{l}\text { Peter et al. 2002; Ala-Mursula et al. 2005; } \\
\text { Chandola et al. 2005; van Vegchel et al. 2005; } \\
\text { Peter et al. 2006 }\end{array}$ \\
\hline $\begin{array}{l}\text { 3. Lack of support from colleagues/supervisor } \\
\text { for first cardiac event }\end{array}$ & $\begin{array}{l}\text { Belkic et al. 2004; De Bacquer et al. 2005; } \\
\text { Kuper et al. 2006; André-Petersson et al. 2007; } \\
\text { Chandola et al. 2008; Eller et al. 2009 }\end{array}$ \\
$\begin{array}{l}\text { 4. Other stressors at work for first cardiac } \\
\text { event: financial setbacks, bankruptcy, not } \\
\text { realizing a promotion, increase or decrease of } \\
\text { responsibility, conflict, too many deadlines, } \\
\text { too much competition at work, too much } \\
\text { criticism of supervisor, change of workplace, } \\
\text { and job dissatisfaction }\end{array}$ & $\begin{array}{l}\text { Falger and Schouten 1992; Ferrie et al. 1995, } \\
\text { 1998, 2002; Kivimäki et al. 2003; Theorell et } \\
\text { al. 2003; Virtanen et al. 2003; Lee et al. 2004; } \\
\text { Vahtera et al. 2004; Müller-Nordhorn et al. } \\
\text { 2003; Gallo et al. 2006; Huisman et al. 2008; } \\
\text { Väänänen et al. 2008; Eller et al. 2009; Fiabane } \\
\text { et al. 2013 }\end{array}$ \\
\hline
\end{tabular}


RTW in patients with cardiovascular disease published between 1994 and 2016, concluded that job strain and job control were the most important predictors of RTW, in addition to work ability.

A high effort-reward imbalance also increases the risk for a first cardiac event.

Recent research by Biering et al. (2015) among PCI patients showed that high work pace, low commitment to the workplace, low recognition (rewards), and low job control were associated with sickness absence at three months, but not after one year.

As Table 3 shows, lack of support from colleagues/supervisor is a risk factor for first cardiac events. There is evidence that other stressors at work also increase the risk for (first) cardiac events. Finally, and also shown in Table 3, there is suggestive evidence that diverse other stressors at work increase the risk for a first cardiac event.

\section{Work-Related Risk Factors: Physical Risk Factors}

For physical risk factors, guidelines already exist and no new review has been performed. These guidelines agree on four physical working environment factors that increase the risk for a cardiac event (Table 4). There is strong evidence for exposure to chemical and physical hazards and to noise. Shift work has direct negative effects on cardiovascular disease but also via a bad lifestyle. The evidence for sedentary work is weak, and often inconclusive, as studies often do not control for active lifestyle, groups are selective, and measures for sedentary work might not be valid. Findings are inconclusive for the following factors. Physically heavy work (e.g., lifting) is only regarded dangerous when performed irregularly by employees with a bad physical endurance. It is recommended that during an 8-hour working day, physical demands do not exceed $30-40 \%$ of VO2 maximal (Wiedeman et al. 1984). For working under extreme temperatures, which might trigger cardiac events, findings are contradictory and, according to the guideline, up to the discretion of occupational physicians (van Dijk et al. 2006).

Table 4 Physical risk factors in the working environment for cardiac events

\begin{tabular}{l|l}
\hline Physical risk factor & References \\
\hline $\begin{array}{l}\text { 1. Chemical and physical hazards, e.g., passive } \\
\text { smoking, carbon monoxide, small particles } \\
(\leq 2.5 \mu \mathrm{m})\end{array}$ & $\begin{array}{l}\text { Allred et al. 1989, He et al. 1999; Peters } \\
\text { et al. 2001; Whincup et al. 2004 }\end{array}$ \\
\hline 2. Noise $(\geq 85 \mathrm{~dB})$ & Babisch et al. 2005; Willich et al. 1993 \\
\hline 3. Shift work & Schnall et al. 2000; Knutsson 2003; \\
\hline $\begin{array}{l}\text { 4. Sedentary work without compensating active } \\
\text { lifestyle }\end{array}$ & van Uffelen et al. 2010 \\
\hline 5. Physically heavy work & Wiedeman et al. 1984 \\
\hline 6. Working under extreme temperatures & $\begin{array}{l}\text { van Dijk et al. 2006; van Stipdonk et al. } \\
\text { 2011 }\end{array}$ \\
\hline
\end{tabular}




\section{Barriers to a Successful RTW}

Many factors prolong sickness absence in cardiac patients. Four areas of psychosocial barriers to RTW can be distinguished: (1) vulnerable social-demographic status; (2) health problems and unhealthy lifestyle; (3) mental health problems; and (4) negative perceptions. In total, 17 barriers to a successful RTW are identified (see Table 5). A recent review that includes studies on factors related to RTW in cardiovascular disease published between 1994 and 2016 parallels these findings (Gragnano et al. 2018).

Social-demographic factors. As Table 5 shows, cardiac patients with low education and/or low social support in their environment have increased risk not to return

Table 5 Barriers to a successful RTW

\begin{tabular}{|c|c|}
\hline $\begin{array}{l}\text { Risk factor for RTW after cardiac } \\
\text { event }\end{array}$ & References \\
\hline \multicolumn{2}{|l|}{ Social-demographic factors } \\
\hline 1. Low education & $\begin{array}{l}\text { Soejima et al. 1999; Söderman et al. 2003; Earle et al. 2006; } \\
\text { Smedegaard et al. 2017; Butt et al. } 2018\end{array}$ \\
\hline $\begin{array}{l}\text { 2. Low social support in their } \\
\text { environment }\end{array}$ & Soejima et al. 1999; Sykes et al. 2000; \\
\hline 3. Female gender & $\begin{array}{l}\text { Kragholm et al. 2015; Dreyer et al. 2016; Smedegaard et al. } \\
\text { 2017; Butt et al. 2018; }\end{array}$ \\
\hline 4. $>50$ years of age & Kragholm et al. 2015; Butt et al. 2018 \\
\hline \multicolumn{2}{|c|}{ Health problems and unhealthy lifestyle } \\
\hline $\begin{array}{l}\text { 5. Persistence of angina } \\
\text { symptoms after hospitalization }\end{array}$ & \multirow{2}{*}{$\begin{array}{l}\text { Froom et al. 1999; Clarke et al. 2000; Shrey and Mital 2000; } \\
\text { Mittag et al. 2001; Kamphuis et al. 2002; Earle et al. 2006; } \\
\text { Samkange-Zeeb et al. 2006; }\end{array}$} \\
\hline $\begin{array}{l}\text { 6. Cardiac health limits daily } \\
\text { functioning }\end{array}$ & \\
\hline $\begin{array}{l}\text { 7. Experience reduced physical } \\
\text { activity on a daily basis }\end{array}$ & \multirow[t]{2}{*}{ Sykes et al. 2000; Mittag et al. 2001; Slebus et al. 2007} \\
\hline 8. Excessive alcohol use & \\
\hline $\begin{array}{l}\text { 9. Prior cardiovascular disease } \\
\text { symptoms }\end{array}$ & \multirow{2}{*}{$\begin{array}{l}\text { Froom et al. 1999; Clarke et al. 2000; Shrey and Mital 2000; } \\
\text { Mittag et al. 2001; Kamphuis et al. 2002; Earle et al. 2006; } \\
\text { Samkange-Zeeb et al. 2006; Butt et al. } 2018\end{array}$} \\
\hline 10. Other health problems & \\
\hline \multicolumn{2}{|l|}{ Mental health problems } \\
\hline 11. Depressive symptoms & $\begin{array}{l}\text { O'Neil et al. 2010; Ervasti et al. 2015; Haschke et al. 2012; } \\
\text { de Jonge et al. 2014; Smedegaard et al. } 2017\end{array}$ \\
\hline 12. Anxiety symptoms & Gragnano et al. 2018; Reibis et al. 2019 \\
\hline \multicolumn{2}{|l|}{ Negative perceptions } \\
\hline $\begin{array}{l}\text { 13. Lack of acceptation of the } \\
\text { illness }\end{array}$ & \multirow{5}{*}{$\begin{array}{l}\text { Clarke et al. 2000; Müller-Nordhorn et al. 2003; Earle et al } \\
\text { 2006; Hemingway et al. 2007; Bergvik et al. 2012; Fiabane } \\
\text { et al. 2013; Söderberg et al. } 2015\end{array}$} \\
\hline 14. Low recovery expectations & \\
\hline 15. Lack of self-confidence & \\
\hline 16. Low internal locus of control & \\
\hline $\begin{array}{l}\text { 17. Lack of job satisfaction or } \\
\text { motivation for RTW }\end{array}$ & \\
\hline
\end{tabular}


Table 6 Norm scores for depression and anxiety in patients with coronary heart disease

\begin{tabular}{l|l|l}
\hline & Depression & Anxiety \\
\hline $\begin{array}{l}\text { First } \\
\text { choice }\end{array}$ & Patient Health Questionnaire 9 items & Generalized Anxiety Disorder 7 items \\
& (PHQ-9) (Spitzer et al. 1999) & (GAD-7) (Spitzer et al. 2006) \\
& Severe: 10-27 & Severe: 10-27 \\
& Moderate: 5-9 & Moderate: 5-9 \\
& Low: 0-4 & Low: 0-4 \\
\hline $\begin{array}{l}\text { Second } \\
\text { choice }\end{array}$ & Beck Depression Inventory (BDI) (Beck & Beck Anxiety Inventory (BAI) (Beck \\
& et al. 1996) & et al. 1988) \\
& Severe: 10-63 & Severe: 10-63 \\
& Moderate: 5-9 & Moderate: 5-9 \\
& Low: 0-4 & Low: 0-4 \\
\hline Third \\
choice & Hospital Anxiety and Depressions Scale- & Hospital Anxiety and Depressions Scale \\
& Depression (HADS-D) (Spinhoven et al. & - Anxiety (HADS-A) (Spinhoven et al. \\
& 1997) & 1997) \\
& Severe: $8-21$ & Severe: 8-21 \\
& Moderate: 5-7 & Moderate: 5-7 \\
& Low: 0-4 & Low: 0-4 \\
\hline
\end{tabular}

to their work. Several recent studies showed that women return to work less than men and, also, older cardiac patients return to work less often than younger patients.

Health problems and unhealthy lifestyle. If patients experience symptoms of angina after hospital dismissal and/or limitations in daily functioning, this hampers their RTW (see Table 5). Unhealthy lifestyle in terms of low physical activity and high alcohol consumption also hamper RTW. Patients with a history of cardiovascular disease are also hampered, as are those who have other health problems. Recently, Butt et al. (2018) found absence of major comorbidities to be associated with return to work 1 year after discharge for CABG.

Mental health problems. Depressive symptoms decrease the RTW chance considerably (the literature on anxiety is scarce but also points toward an increased risk for less RTW). Levels of depression and anxiety can be measured via assessment instruments (questionnaires). In the context of the guideline development, a systematic review and meeting with a specific working group of psychologists was organized to establish the top 3 of best assessment instruments (leaving discretion to the hospitals) with corresponding norm scores (van Engen-Verheul et al. 2012) (Table 6). Severe levels of depression and/or anxiety are an indication for a diagnostic interview to judge whether the patient fulfills the criteria for a depressive disorder or anxiety disorder or not. Low levels, though, indicate the absence of a risk factor. The HADS is widely accepted in hospitals, but psychometric qualities are low, particularly for anxiety, even though Reibis et al. (2019) recommend the HADS to assess psychosocial parameters to improve RTW after an acute coronary syndrome such as MI.

Negative perceptions. As Table 5 shows, lack of acceptation of the illness, low recovery expectations, lack of self-confidence, and lower internal locus of control and motivation for RTW are all related to lower RTW rates. These negative thoughts that function as barriers to RTW might be explained by depression and/or might be 
rooted in adverse psychosocial working conditions. Söderberg et al. (2015) demonstrated in a cross-sectional study that such conditions are related to lower RTW expectations via fear-avoidance beliefs toward the workplace.

\section{RTW Interventions for Employees with Coronary Heart Disease}

Thirteen studies on RTW interventions for cardiac patients that met the inclusion criteria (published between January 2000 and September 2018; listed in PsycINFO, CINAHL, PubMed; evaluation study of RTW intervention in patients with a coronary heart disease) are included. Positive effects of interventions are found for ten of the interventions (Mital et al. 2000; Varvaro 1991; Higgins et al. 2001; Kutzleb and Reiner 2006; Hanssen et al. 2007; Broadbent et al. 2009; McKee 2009; Lamberti et al. 2016; Babić et al. 2015; Pirhonen et al. 2017). Generally, they are more comprehensive than the three interventions that did not yield results (Pfund 2001; Hanssen et al. 2009; Yonezawa et al. 2009). Still, the effective interventions vary largely regarding content. They include interventions focusing on reduction of barriers in terms of lifestyle, physical condition, and psychological symptoms by health education strategies; making a return-to-work plan; occupational counselling; establishing work modifications; and extensive assessment of the patient's condition in order to advise on when to return to work. Lamberti et al. (2016) and Babić et al. (2015) demonstrate that lack or delayed CR was related to reduced RTW. In checking the references of the hits, another four studies of fair quality were found that had been published before 2000 but had not been included in the review of Perk and Alexanderson (2004) (Picard et al. 1989; Haussler and Keck 1997; Dumont et al. 1999; Johnston et al. 1999). These studies present extensive and effective interventions. For example, one German intervention included a guided trajectory consisting of making up a problem analysis and a reintegration plan during rehabilitation; next a meeting with the employer regarding work modifications; and finally administrative and psychological support to safeguard RTW (Haussler and Keck 1997). The recent study by Pirhonen et al. (2017) showed positive effects of person-centered care on increased self-efficacy, but the positive effects on RTW were nonsignificant due to too short follow-up. Their intervention consists of patients and clinicians identifying and discussing problems and next considering both the outcomes of clinical tests and the practical, social, and emotional effects of their condition(s) and treatment(s) on their daily lives. A shared decision-making process informs a plan of action. O'Brien et al. (2018) showed with a meta-analysis of 18 RTW interventions for MI patients, a 3-month increase in RTW rate compared to usual care.

\section{Recommendations by Experts for the Support of RTW in CR}

On the basis of the scientific literature and expert opinion, a RTW support procedure within $\mathrm{CR}$ is recommended (Fig. 1). Basically, this procedure aligns with the support strategies that Reibis et al. (2019) recommend after CR. 


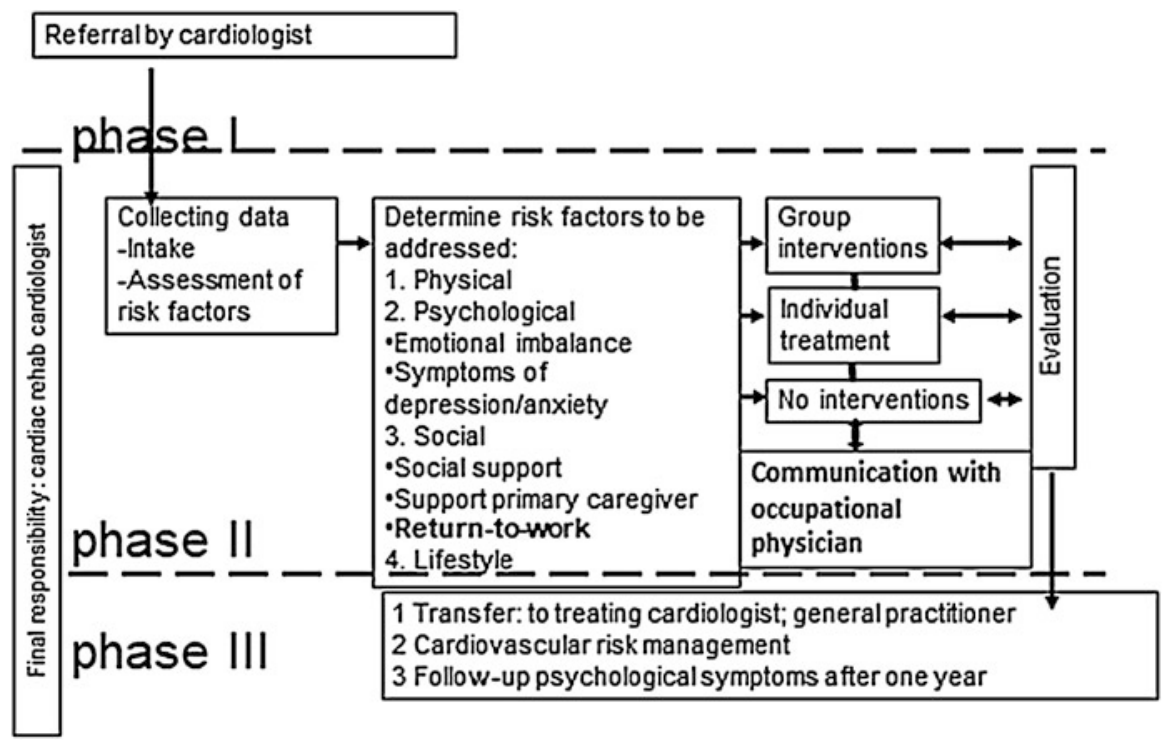

Fig. 1 RTW support procedure within CR

In essence, the RTW support procedure needs to be tailored to the cardiac patient's individual risk factors and should be comprehensive enough the tackle risk factors for CVD and barriers to RTW. Further, the experts, with the occupational physicians in particular, advocate for gradual RTW during CR, so CR patients are supported by the CR team and have plenty opportunities to discuss work-related problems. Indeed, system delays decrease RTW (Laut et al. 2014). Reibis et al. (2019) also emphasize part-time, stepwise reintegration into work. However, they envision that RTW support is part of prolonged CR, rather than an integral part of CR. Because prolonged CR hardly exists across different countries (Reibis et al. 2019), it is recommended though to incorporate RTW support within regular CR.

The RTW support procedure should start with referral of the patient to CR by the treating cardiologist. To target the RTW support and align with other services, first, whether the patient has a work-related problem and is in need of RTW support needs to be checked and, if so, the risk factors from Tables 2, 3, 4, and 5 be assessed (the CR-WORK checklist with questions to support targeting during the intake for CR is available with the author upon request). In line with this, Reibis et al. (2019) also recommend risk stratification and making up a work-related diagnosis.

This assessment requires a trained nurse or reintegration professional. On the basis of risks for hampered RTW, interventions within and outside the CR/hospital setting need to be selected and be prioritized together with the patient (the CR matrix with RTW interventions and referral options within and outside the hospital is available with the author upon request). In line with privacy laws, it is of utmost importance that healthcare workers do not contact the employer directly but communicate via the occupational physician and patient. This is to avoid (1) that 
employers receive medical, and thus private, information and (2) bypassing a possible occupational physician who - if available in a country's system - has a key role in translating medical status into work opportunities. Further and in line with the law on exchange of medical information, patients need to agree with the cardiologist on sending medical information to his or her occupational physician (if available). Lack of clarity regarding legislation and roles might lead to a reserved attitude regarding RTW support of cardiac patients.

During the support procedure, all CR professionals should monitor the patient's (steps toward) gradual RTW and the bottlenecks experienced by (in)formal talks with the patient, discuss the monitoring results in interdisciplinary meetings, and take adequate action if needed. Finally, the intervention results need to be evaluated. Within a CR setting, this is after 2-3 months. If the results are satisfying for the patient and professionals, the patient is transferred to guidance by the treating physician.

As part of the guideline project, we did a pilot study on using the CR-WORK checklist in one hospital during 2 weeks. Generally, the healthcare workers acknowledged two types of patients: those who feel pressed by the return to their work and those who hesitated to return to work and searched for ways to legitimize the delay of their RTW. The healthcare workers preferred a checklist format that fits their work routines. Also, the healthcare workers needed more knowledge about interventions to manage the risk factors and a standardized "tick-box format" letter to communicate with the patients' occupational physician.

\section{Conclusions}

There is evidence that specific support for RTW within CR improves the RTW rate, but interventions vary widely and are not integrated well in CR nor address the various types of risks. In this chapter, it is proposed to target the cardiac patients in need of RTW support, to screen them for risk factors, and to select interventions that fit with the individual risk factors, which are delivered both within and outside CR.

The review results have led to a guideline for RTW within CR in the Netherlands (van Stipdonk et al. 2011) and have implications for CR in other countries. In many countries, occupational physicians are not available or do not have tasks regarding RTW guidance. Even though in the Netherlands, occupational physicians have a key role in RTW guidance, they are not available to an increasing number of patients at working age (e.g., the self-employed, those working for temporary agencies, etc.). Bridging hospital treatment (rehabilitation) with workplace requirements is thus a bottleneck in all countries. CR is of utmost importance to support cardiac patients in their RTW (Piepoli et al. 2010; Reibis et al. 2019). It can be concluded that RTW guidance should be part of CR in order not to delay RTW unnecessarily and offer the patient tailor-made support. Standardized checklists such as the CR-WORK checklist, valid psychological questionnaires, and the CR matrix with RTW interventions offer healthcare workers more grip on an important aspect of CR that they might be insecure about. Reintegration agencies outside hospitals can also use the information 
in this chapter to develop their interventions. Next, the effectiveness of the new checklist and the intervention recommendations need to be studied in studies of high quality.

\section{Cross-References}

An Integrative Framework for Return to Work After Common Mental Disorders

- Employment as a Key Rehabilitation Outcome

- Implementing Best Practice Models of Return to Work

Investing in Medical and Vocational Rehabilitation Services

- Legal Aspects of Access/Return to Work

Mental Disabilities

- Occupational Determinants of Cardiovascular Disorders Including Stroke

> Promoting Workplace Mental Wellbeing

- Socio-Environmental and Psychological Barriers to Employment

- The Impact of Working Conditions on Health Among People with and without Disability

\section{References}

Ala-Mursula L, Vahtera J, Linna A, Pentti J, Kivimäki M (2005) Employee worktime control moderates the effects of job strain and effort-reward imbalance on sickness absence: the 10-town study. J Epidemiol Community Health 59:851-857

Allred EN, Bleecker ER, Chaitman BR, Dahms TE, Gottlieb SO, Hackney JD, Hayes D, Pagano M, Selvester RH, Walden SM (1989) Acute effects of carbon monoxide exposure on individuals with coronary artery disease. Res Rep Health Eff Inst 25:1-79

André-Petersson L, Engström G, Hedblad B, Janzon L, Rosvall M (2007) Social support at work and the risk of myocardial infarction and stroke in women and men. Soc Sci Med 64:830-834

Babić Z, Pavlov M, Oštrić M, Milošević M, Misigoj Duraković M, Pintarić H (2015) Re-initiating professional working activity after myocardial infarction in primary percutaneous coronary intervention networks era. Int J Occup Med Environ Health 28:999-1010

Babisch W, Beule B, Schust M, Kersten N, Ising H (2005) Traffic noise and risk of myocardial infarction. Epidemiology 16:33-40

Beck AT, Epstein N, Brown G, Steer RA (1988) An inventory for measuring clinical anxiety: psychometric properties. J Consult Clin Psychol 56:893-897

Beck AT, Steer RA, Ball R, Ranieri WF (1996) Comparison of Beck Depression Inventories-I and II in psychiatric outpatients. J Pers Assess 67:588-597

Belkic KL, Landsbergis PA, Schnall PL, Baker D (2004) Is job strain a major source of cardiovascular disease risk? Scand J Work Environ Health 30:85-128

Bergvik S, Sørlie T, Wynn R (2012) Coronary patients who returned to work had stronger internal locus of control beliefs than those who did not return to work. Br J Health Psychol 17(5):96-608

Biering K, Lund T, Andersen JH, Hjollund NH (2015) Effect of psychosocial work environment on sickness absence among patients treated for ischemic heart disease. J Occup Rehabil 25:776-782

Bjarnason-Wehrens B, Mayer-Berger W, Meister ER, Baum K, Hambrecht R, Gielen S (2004) German Federation for Cardiovasular Prevention and Rehabilitation. Recommendations for resistance exercise in cardiac rehabilitation. Eur J Cardiovasc Prev Rehabil 11:352-361 
Bonde JP, Munch-Hansen T, Agerbo E, Suadicani P, Wieclaw J, Westergaard-Nielsen N (2009) Job strain and ischemic heart disease: a prospective study using a new approach for exposure assessment. J Occup Environ Med 51:732-738

Boschetto P, Vaccari A, Groccia R, Casimirri E, Stendardo M, Maietti E, Volpato S, Sarcone M, Fucili A (2016) Forced expiratory volume in one second: predicting return to work within 3 months after chronic heart failure diagnosis. Int J Cardiol 203:798-799

Broadbent E, Ellis CJ, Thomas J, Gamble G, Petrie KJ (2009) Further development of an illness perception intervention for myocardial infarction patients: a randomized controlled trial. J Psychosom Res 67:17-23

Butt JH, Rørth R, Kragholm K, Kristensen SL, Torp-Pedersen C, Gislason GH, Køber L, Fosbøl EL (2018) Return to the workforce following coronary artery bypass grafting: a Danish nationwide cohort study. Int J Cardiol 251:15-21

Chandola T, Siegrist J, Marmot M (2005) Do changes in effort-reward imbalance at work contribute to an explanation of the social gradient in angina? Occup Environ Med 62:223-230

Chandola T, Britton A, Brunner E, Hemingway H, Malik M, Kumari M, Badrick E, Kivimäki M, Marmot M (2008) Work stress and coronary heart disease: what are the mechanisms? Eur Heart J 29:640-648

Clarke SP, Frasure-Smith N, Lespérance F, Bourassa MG (2000) Psychosocial factors as predictors of functional status at 1 year in patients with left ventricular dysfunction. Res Nurs Health 23:290-300

De Bacquer D, Pelfrene E, Clays E, Mak R, Moreau M, De Smet P, Kornitzer M, De Backer G (2005) Perceived job stress and incidence of coronary events: 3-year follow-up of the Belgian Job Stress Project cohort. Am J Epidemiol 161:434-441

de Jong MJ, Chung ML, Roser LP, Jensen LA, Kelso LA, Dracup K, McKinley S, Yamasaki K, Kim CJ, Riegel B, Ball C (2004) A five-country comparison of anxiety early after acute myocardial infarction. Eur J Cardiovasc Nurs 3:129-134

de Jonge P, Zuidersma M, Bültmann U (2014) The presence of a depressive episode predicts lower return to work rate after myocardial infarction. Gen Hosp Psychiatry 36:363-367

Dreyer RP, Xu X, Zhang W, Du X, Strait KM, Bierlein M, Bucholz EM, Geda M, Fox J, D’Onofrio G, Lichtman JH, Bueno H, Spertus JA, Krumholz HM (2016) Return to work after acute myocardial infarction: comparison between young women and men. Circ Cardiovasc Qual Outcomes 9:S45-S52

Dumont S, Jobin J, Deshaies G, Trudel L, Chantale M (1999) Rehabilitation and the sociooccupational reintegration of workers who have had a myocardial infarct: a pilot study. Can J Cardiol 15:453-461

Eaker ED, Sullivan LM, Kelly-Hayes M, D’Agostino RB Sr, Benjamin EJ (2004) Does job strain increase the risk for coronary heart disease or death in men and women? The Framingham offspring study. Am J Epidemiol 159:950-958

Earle A, Ayanian JZ, Heymann J (2006) Work resumption after newly diagnosed coronary heart disease: findings on the importance of paid leave. J Women's Health 15:430-441

Eller NH, Netterstrøm B, Gyntelberg F, Kristensen TS, Nielsen F, Steptoe A, Theorell T (2009) Work-related psychosocial factors and the development of ischemic heart disease: a systematic review. Cardiol Rev 17:83-97

Ervasti J, Vahtera J, Pentti J, Oksanen T, Ahola K, Kivekäs T, Kivimäki M, Virtanen M (2015) Return to work after depression-related absence by employees with and without other health conditions: a cohort study. Psychosom Med 77:126-135

Falger PR, Schouten EG (1992) Exhaustion, psychological stressors in the work environment, and acute myocardial infarction in adult men. J Psychosom Res 36:777-786

Ferrie JE, Shipley MJ, Marmot MG, Stansfeld S, Smith GD (1995) Health effects of anticipation of job change and non-employment: longitudinal data from the Whitehall II study. BMJ 311:1264-1269 
Ferrie JE, Shipley MJ, Marmot MG, Stansfeld SA, Smith GD (1998) An uncertain future: the health effects of threats to employment security in white-collar men and women. Am J Public Health 88:1030-1036

Ferrie JE, Shipley MJ, Smith GD, Stansfeld SA, Marmot MG (2002) Change in health inequalities among British civil servants: the Whitehall II study. J Epidemiol Community Health 56:922926

Fiabane E, Argentero P, Calsamiglia G, Candura SM, Giorgi I, Scafa F, Rugulies R (2013) Does job satisfaction predict early return to work after coronary angioplasty or cardiac surgery? Int Arch Occup Environ Health 86:561-569

Froom P, Cohen C, Rashcupkin J, Kristal-Boneh E, Melamed S, Benbassat J, Ribak J (1999) Referral to occupational medicine clinics and resumption of employment after myocardial infarction. J Occup Environ Med 41:943-947

Gallo WT, Teng HM, Falba TA, Kasl SV, Krumholz HM, Bradley EH (2006) The impact of late career job loss on myocardial infarction and stroke: a 10 year follow up using the health and retirement survey. Occup Environ Med 63:683-687

Gragnano A, Negrini A, Miglioretti M, Corbiere M (2018) Common psychosocial factors predicting return to work after common mental disorders, cardiovascular diseases, and cancers: a review of reviews supporting a cross-disease approach. J Occup Rehabil 28:215-231

Hanssen TA, Nordrehaug JE, Eide GE, Hanestad BR (2007) Improving outcomes after myocardial infarction: a randomized controlled trial evaluating effects of a telephone follow-up intervention. Eur J Cardiovasc Prev Rehabil 14:429-437

Hanssen TA, Nordrehaug JE, Eide GE, Hanestad BR (2009) Does a telephone follow-up intervention for patients discharged with acute myocardial infarction have long-term effects on healthrelated quality of life? A randomised controlled trial. J Clin Nursing 18:1334-1345

Haschke A, Hutter N, Baumeister H (2012) Indirect costs in patients with coronary artery disease and mental disorders: a systematic review and meta-analysis. Int J Occup Med Environ Health 25:319-329

Haussler B, Keck M (1997) Improvement in occupational rehabilitation of myocardial infarct patients - results of a model study in Rhineland-Pfalz. Rehabilitation 36:106-110

He J, Vupputuri S, Allen K, Prerost MR, Hughes J, Whelton PK (1999) Passive smoking and the risk of coronary heart disease - a meta-analysis of epidemiologic studies. New Engl J Med 25:920-926

Hemingway H, Vahtera J, Virtanen M, Pentti J, Kivimäki M (2007) Outcome of stable angina in a working population: the burden of sickness absence. Eur J Cardiovasc Prev Rehabil 14:373-379

Heran BS, Chen JM, Ebrahim S, Moxham T, Oldridge N, Rees K, Thompson DR, Taylor RS (2011) Exercise-based cardiac rehabilitation for coronary heart disease. Cochrane Database Syst Rev CD001800

Higgins HC, Hayes RL, McKenna KT (2001) Rehabilitation outcomes following percutaneous coronary interventions (PCI). Patient Educ Couns 43:219-230

Huisman M, Van Lenthe F, Avendano M, Mackenbach J (2008) The contribution of job characteristics to socioeconomic inequalities in incidence of myocardial infarction. Soc Sci Med 66:2240-2252

Jelinek M (2014) Resumption of work after acute coronary syndrome or coronary artery bypass surgery. Heart Lung Circ 23:1094

Johnston M, Foulkes J, Johnston DW, Pollard B, Gudmundsdottir H (1999) Impact on patients and partners of inpatient and extended cardiac counseling and rehabilitation: a controlled trial. Psychosom Med 61:225-233

Jolliffe JA, Rees K, Taylor RS, Thompson D, Oldridge N, Ebrahim S (2001) Exercise-based rehabilitation for coronary heart disease. Cochrane Database Syst Rev CD001800

Kamphuis M, Ottenkamp J, Vliegen HW, Vogels T, Zwinderman KH, Kamphuis RP, VerlooveVanhorick SP (2002) Health related quality of life and health status in adult survivors with previously operated complex congenital heart disease. Heart 87:356-362 
Kivimäki M, Vahtera J, Elovainio M, Pentti J, Virtanen M (2003) Human costs of organizational downsizing: comparing health trends between leavers and stayers. Am J Community Psychol 32:57-67

Kivimäki M, Virtanen M, Elovainio M, Kouvonen A, Väänänen A, Vahtera J (2006) Work stress in the etiology of coronary heart disease-a meta-analysis. Scand J Work Environ Health $32: 431-442$

Knutsson A (2003) Health disorders of shift workers. Occup Med 53:103-108

Kornitzer M, Desmet P, Sans S, Dramaix M, Boulenguez C, DeBacker G, Ferrario M, Houtman I, Isacsson SO, Ostergren PO, Peres I (2006) Job stress and major coronary events: results from the Job Stress, Absenteeism and Coronary Heart Disease in Europe study. Eur J Cardiovasc Prev Rehabil 13:695-704

Kraal JJ, Van den Akker-Van Marle ME, Abut-Hanna A, Stut W, Peek N, Kemps HMC (2017) Clinical and cost-effectiveness of home-based cardiac rehabilitation compared to conventional, centre-based cardiac rehabilitation: results of the FIT@Home study. Eur J Prev Cardiol 24:1260-1273

Kragholm K, Wissenberg M, Mortensen RN, Fonager K, Jensen SE, Rajan S, Lippert FK, Christensen EF, Hansen PA, Lang-Jensen T, Hendriksen OM, Kober L, Gislason G, TorpPedersen C, Rasmussen BS (2015) Return to work in out-of-hospital cardiac arrest survivors: a nationwide register-based follow-up study. Circulation 131:1682-1690

Kuper H, Adami HO, Theorell T, Weiderpass E (2006) Psychosocial determinants of coronary heart disease in middle-aged women: a prospective study in Sweden. Am J Epidemiol 164:349-457

Kutzleb J, Reiner D (2006) The impact of nurse-directed patient education on quality of life and functional capacity in people with heart failure. J Am Acad Nurse Pract 18:116-123

Lallukka T, Martikainen P, Reunanen A, Roos E, Sarlio-Lähteenkorva S, Lahelma E (2006) Associations between working conditions and angina pectoris symptoms among employed women. Psychosom Med 8:348-354

Lamberti M, Ratti G, Gerardi D, Capogrosso C, Ricciardi G, Fulgione C, Latte S, Tammaro P, Covino G, Nienhaus A, Grazillo EM, Mallardo M, Capogrosso P (2016) Work-related outcome after acute coronary syndrome: implications of complex cardiac rehabilitation in occupational medicine. Int J Occup Med Environ Health 29:649-657

Laut KG, Hjort J, Engstrøm T, Jensen LO, Tilsted Hansen HH, Jensen JS, Pedersen F, Jørgensen E, Holmvang L, Pedersen AB, Christensen EF, Lippert F, Lang-Jensen T, Jans H, Hansen PA, Trautner S, Kristensen SD, Lassen JF, Lash TL, Clemmensen P, Terkelsen CJ (2014) Impact of health care system delay in patients with ST-elevation myocardial infarction on return to labor market and work retirement. Am J Cardiol 114:1810-1816

Lee S, Colditz GA, Berkman LF, Kawachi I (2004) Prospective study of job insecurity and coronary heart disease in US women. Ann Epidemiol 14:24-30

Malinauskiene V, Theorell T, Grazuleviciene R, Malinauskas R, Azaraviciene A (2004) Low job control and myocardial infarction risk in the occupational categories of Kaunas men, Lithuania. J Epidemiol Community Health 58:131-135

McKee G (2009) Are there meaningful longitudinal changes in health related quality of life-SF36, in cardiac rehabilitation patients? Eur J Cardiovasc Nurs 8:40-47

Mital A, Shrey DE, Govindaraju M, Broderick TM, Colon-Brown K, Gustin BW (2000) Accelerating the return to work (RTW) chances of coronary heart disease (CHD) patients: part 1 - development and validation of a training programme. Disabil Rehabil 22:604-620

Mittag O, Kolenda KD, Nordman KJ, Bernien J, Maurischat C (2001) Return to work after myocardial infarction/coronary artery bypass grafting: patients' and physicians' initial viewpoints and outcome 12 months later. Soc Sci Med 52:1441-1450

Müller-Nordhorn J, Gehring J, Kulig M, Binting S, Klein G, Gohlke H, Völler H, Bestehorn K, Krobot KJ, Willich SN (2003) Return to work after cardiologic rehabilitation. Sozial- und Praventivmedizin 48:370-378 
Nomura K, Nakao M, Sato M, Ishikawa H, Yano E (2007) The association of the reporting of somatic symptoms with job stress and active coping among Japanese white-collar workers. J Occup Health 49:370-375

O’Brien L, Wallace S, Romero L (2018) Effect of psychosocial and vocational interventions on return-to-work rates post-acute myocardial infarction: a systematic review. J Cardiopulm Rehabil Prev 38:215-223

O'Hagan FT, Coutu MF, Thomas SG, Mertens D (2012) Work reintegration and cardiovascular disease: medical and rehabilitation influences. J Occup Rehabil 22:270-281

O'Neil A, Sanderson K, Oldenburg B (2010) Depression as a predictor of work resumption following myocardial infarction (MI): a review of recent research evidence. Health Qual Life Outcomes 8:95

Perk J, Alexanderson K (2004) Sick leave due to coronary artery disease or stroke. Scand J Public Health 32(63S):181-206

Peter R, Siegrist J, Hallqvist J, Reuterwall C, Theorell T (2002) Psychosocial work environment and myocardial infarction: improving risk estimation by combining two complementary job stress models in the SHEEP Study. J Epidemiol Community Health 56:294-300

Peter R, Hammarström A, Hallqvist J, Siegrist J, Theorell T, SHEEP Study Group (2006) Does occupational gender segregation influence the association of effort-reward imbalance with myocardial infarction in the SHEEP study? Int J Behav Med 13:34-43

Peters A, Dockery DW, Muller JE, Mittleman MA (2001) Increased particulate air pollution and the triggering of myocardial infarction. Circulation 103:2810-2815

Pfund A (2001) Coronary intervention and occupational rehabilitation - a prospective, randomized intervention study. Z Kardiol 90:655-660

Picard MH, Dennis C, Schwartz RG, Ahn DK, Kraemer HC, Berger WE III, Blumberg R, Heller R, Lew H, DeBusk RF (1989) Cost-benefit analysis of early return to work after uncomplicated acute myocardial infarction. Am J Cardiol 63:1308-1314

Piepoli MF, Corra U, Benzer W, Bjarnason-Wehrens B, Dendale P, Gaita D, McGee H, Mendes M, Niebauer J, Zwisler AD, Schmid JP (2010) Seconday prevention through cardiac rehabilitation: from knowledge to implementation. A position paper from the Cardiac Rehabilitation Section of the European Association of Cardiovascular Prevention and Rehabilitation. Eur J Cardiovasc Prev Rehabil 17:1-17

Piepoli MF, Hoes AW, Agewall S, Albus C, Brotons C, Catapano AL, Cooney MT, Corra U, Cosyns B, Deaton C, Graham I, Hall MS, Hobbs FDR, Løchen M-L, Löllgren H, Marques-Vidal P, Perk J, Prescott E, Redon J, Richter DJ, Sattar N, Smulders Y, Tiberi M, van der Worp BH, van Dis I, Verschuren M (2016) European guidelines on cardiovascular disease prevention in clinical practice: The Sixth Joint Task Force of the European Society of Cardiology and Other Societies on Cardiovascular Disease Prevention in Clinical Practice (constituted by representatives of 10 societies and by invited experts) Developed with the special contribution of the European Association for Cardiovascular Prevention \& Rehabilitation (EACPR). Eur Heart J 37:2315-2381

Pirhonen L, Olofsson EH, Fors A, Ekman I, Bolin K (2017) Effects of person-centred care on health outcomes-A randomized controlled trial in patients with acute coronary syndrome. Health Policy 121:169-179

Reibis R, Salzwedel A, Abreu A, Corra U, Davos C, Doehner W, Doherty P, Frederix I, Hansen D, Iliou M, Vigorito C, Völler H (2019) The importance of return to work: How to achieve optimal reintegration in ACS patients. Eur J Prev Cardiol 26:1358-1369

Riese H, Van Doornen LJ, Houtman IL, De Geus EJ (2004) Job strain in relation to ambulatory blood pressure, heart rate, and heart rate variability among female nurses. Scand J Work Environ Health 30:477-485

Salzwedel A, Reibis R, Wegscheider K, Eichler S, Buhlert H, Kaminski S, Völler H (2016) Cardiopulmonary exercise testing is predictive of return to work in cardiac patients after multicomponent rehabilitation. Clin Res Cardiol 105:257-267 
Samkange-Zeeb F, Altenhöner T, Berg G, Schott T (2006) Predicting non-return to work in patients attending cardiac rehabilitation. Int J Rehabil Res 29:43-49

Schnall P, Belkić K, Landsbergis P, Baker D (2000) Why the workplace and cardiovascular disease? Occup Med 15:1-6

Shrey DE, Mital A (2000) Accelerating the return to work (RTW) chances of coronary heart disease (CHD) patients: part 2 - development and validation of a vocational rehabilitation programme. Disabil Rehabil 22:621-626

Slebus FG, Kuijer PP, Willems HJ, Sluiter JK, Frings-Dresen MH (2007) Prognostic factors for work ability in sicklisted employees with chronic diseases. Occup Environ Med 64:814-819

Smedegaard L, Numé AK, Charlot M, Kragholm K, Gislason G, Hansen PR (2017) Return to work and risk of subsequent detachment from employment after myocardial infarction: insights from Danish nationwide registries. J Am Heart Assoc 10:e06486

Söderberg M, Rosengren A, Gustavsson S, Schiöler L, Härenstam A, Torén K (2015) Psychosocial job conditions, fear avoidance beliefs and expected return to work following acute coronary syndrome: a cross-sectional study of fear-avoidance as a potential mediator. BMC Public Health $15: 1263$

Söderman E, Lisspers J, Sundin O (2003) Depression as a predictor of return to work in patients with coronary artery disease. Soc Sci Med 56:193-202

Soejima Y, Steptoe A, Nozoe SI, Tei C (1999) Psychosocial and clinical factors predicting resumption of work following acute myocardial infarction in Japanese men. Int J Cardiol 72:39-47

Spinhoven P, Ormel J, Sloekers PP, Kempen GI, Speckens AE, Van Hemert AM (1997) A validation study of the Hospital Anxiety and Depression Scale (HADS) in different groups of Dutch subjects. Psychol Med 27:363-370

Spitzer RL, Kroenke K, Williams JB (1999) Validation and utility of a self-report version of PRIME-MD: the PHQ primary care study. JAMA 282:1737-1744

Spitzer RL, Kroenke K, Williams JB, Lowe B (2006) A brief measure for assessing generalized anxiety disorder. The GAD-7. Arch Intern Med 166:1092-1097

Sykes DH, Hanley M, Boyle DM, Higginson JDS (2000) Work strain and the post-discharge adjustment of patients following a heart attack. Psychol Health 15:609-623

Theorell T, Oxenstierna G, Westerlund H, Ferrie J, Hagberg J, Alfredsson L (2003) Downsizing of staff is associated with lowered medically certified sick leave in female employees. Occup Environ Med 60:E9

Thombs BD, Bass EB, Ford DE, Stewart KJ, Tsilidis KK, Patel U, Fauerbach JA, Bush DE, Ziegelstein RC (2006) Prevalence of depression in survivors of acute myocardial infarction. J Gen Intern Med 21:30-38

Väänänen A, Koskinen A, Joensuu M, Kivimäki M, Vahtera J, Kouvonen A, Jäppinen P (2008) Lack of predictability at work and risk of acute myocardial infarction: an 18-year prospective study of industrial employees. Am J Public Health 98:2264-2271

Vahtera J, Kivimäki M, Pentti J, Linna A, Virtanen M, Virtanen P, Ferrie JE (2004) Organisational downsizing, sickness absence, and mortality: 10-town prospective cohort study. BMJ 328:555

van Dijk JL, Bekedam MA, Brouwer W, Buijvoets M, Gielen CMJ, Jambroes G, Robeer GG, Smeenk D, Willems MLN (2006) Achtergronddocument bij de richtlijn ischemische hartziekten. Handelen van de bedrijfsarts bij werknemers met ischemische hartziekten. NVAB Kwaliteitsbureau, Utrecht

van Engen-Verheul MM, de Rijk AE, Peek N (eds) (2012) Beslisboom Poliklinische Indicatiestelling Hartrevalidatie 2012. Nederlandse Vereniging voor Cardiologie, Utrecht

van Stipdonk T, Kuijpers P, de Rijk A, van Dijk J, projectgroep PAAHR (2011) Interventies gericht op sociale doelen. In: Revalidatiecommissie NVVC/NHS en projectgroep PAAHR (ed) Multidisciplinaire Richtlijn Hartrevalidatie 2011. Nederlandse Vereniging Voor Cardiologie, Utrecht van Uffelen JG, Wong J, Chau JY, van der Ploeg HP, Riphagen I, Gilson ND, Burton NW, Healy GN, Thorp AA, Clark BK, Gardiner PA (2010) Occupational sitting and health risks: a systematic review. Am J Prev Med 39:379-388

van Vegchel N, De Jonge J, Bosma H, Schaufeli W (2005) Reviewing the effort-reward imbalance model: drawing up the balance of 45 empirical studies. Soc Sci Med 60:1117-1131 
Varvaro FF (1991) Women with coronary heart disease: an application of Roy's Adaptation Model. Cardiovasc Nurs 27:31-35

Virtanen M, Kivimäki M, Elovainio M, Vahtera J, Ferrie JE (2003) From insecure to secure employment: changes in work, health, health related behaviours, and sickness absence. Occup Environ Med 60:948-953

Wang HX, Leineweber C, Kirkeeide R, Svane B, Schenck-Gustafsson K, Theorell T, Orth-Gomér K (2007) Psychosocial stress and atherosclerosis: family and work stress accelerate progression of coronary disease in women. The Stockholm Female Coronary Angiography Study. J Intern Med 26:245-254

Whincup PH, Gilg JA, Emberson JR, Jarvis MJ, Feyerabend C, Bryant A, Walker M, Cook DG (2004) Passive smoking and risk of coronary heart disease and stroke: prospective study with cotinine measurement. BMJ 329:200-205

Wiedeman HP, Gee JB, Balmes JR, Loke J (1984) Exercise testing in occupational lung disease. Clin Chest Med 5:157-171

Willich S, Lewis M, Lowel H (1993) Physical exertion as a trigger of acute myocardial infarction. N Engl J Med 329:1684-1690

Worcester MU, Elliott PC, Turner A, Pereira JJ, Murphy BM, Le Grande MR, Middleton KL, Navaratnam HS, Nguyen JK, Newman RW, Tatoulis J (2014) Resumption of work after acute coronary syndrome or coronary artery bypass graft surgery. Heart Lung Circ 23:444-453

Yonezawa R, Masuda T, Matsunaga A, Takahashi Y, Saitoh M, Ishii A, Kutsuna T, Matsumoto T, Yamamoto K, Aiba N, Hara M (2009) Effects of phase II cardiac rehabilitation on job stress and health-related quality of life after return to work in middle-aged patients with acute myocardial infarction. Int Heart J 50:279-290 